\title{
Bacterial assemblage structure and carbon metabolism along a productivity gradient in the NE Atlantic Ocean
}

\author{
Laura Alonso-Sáez ${ }^{1, *}$, Javier Arístegui ${ }^{2}$, Jarone Pinhassi ${ }^{3}$, Laura Gómez-Consarnau ${ }^{3}$, \\ José M. González ${ }^{4}$, Dolors Vaqué ${ }^{1}$, Susana Agustí ${ }^{\text {, Josep M. Gasol }}{ }^{1}$ \\ ${ }^{1}$ Departament de Biologia Marina i Oceanografia, Institut de Ciències del Mar - CSIC, Pg. Marítim de la Barceloneta 37-49, \\ 08003 Barcelona, Catalunya, Spain \\ ${ }^{2}$ Departamento de Biología, Universidad de las Palmas de Gran Canaria, Campus Universitario de Tafira, PO Box 550 , \\ 35017 Las Palmas de Gran Canaria, Spain \\ ${ }^{3}$ Marine Microbiology, Department of Biology and Environmental Sciences, University of Kalmar, Barlastgatan 11, \\ 39182 Kalmar, Sweden \\ ${ }^{4}$ Departamento de Microbiología y Biología Celular, Facultad de Farmacia, Universidad de La Laguna, Avda. Astrofísico \\ Francisco Sánchez s/n 38071 La Laguna, Tenerife, Spain \\ ${ }^{5}$ Institut Mediterrani d'Estudis Avançats (IMEDEA), CSIC-Universitat de les Illes Balears, Miquel Marquès, 21, \\ 07190 Esporles, Mallorca, Spain
}

\begin{abstract}
Bacterioplankton have the potential to significantly affect the cycling of organic matter in the ocean; however, little is known about the linkage between bacterial assemblage structure and carbon metabolism. In this study, we investigated whether changes in the phylogenetic composition of bacterioplankton were associated with changes in bacterial carbon processing (bacterial production, respiration and biomass) in the subtropical NE Atlantic Ocean. We found consistent differences in the composition of the bacterial assemblage, as revealed by denaturing gradient gel electrophoresis (DGGE) and catalyzed reporter deposition-fluorescence in situ hybridization (CARD-FISH), along a gradient from the NW African upwelling to the oligotrophic North Atlantic Subtropical Gyre. The percent contribution of Bacteroidetes, Roseobacter and Gammaproteobacteria significantly increased towards more productive waters, whereas the SAR11 clade of the Alphaproteobacteria remained relatively constant (average $28 \%$ of DAPI-stained cells) throughout the area. Changes in the composition of the bacterial assemblage detected by DGGE were weakly but significantly correlated with changes in carbon processing variables. The abundances of Roseobacter and Gammaproteobacteria were highly correlated with the concentration of particulate organic carbon and chlorophyll $a$, reflecting the affinity of these groups to nutrient-enriched conditions. The abundance of Roseobacter was also positively correlated with heterotrophic bacterial production, suggesting their active participation in carbon processing.
\end{abstract}

KEY WORDS: Bacteria · Atlantic Ocean · Diversity · Metabolism · CARD-FISH · DGGE Resale or republication not permitted without written consent of the publisher

\section{INTRODUCTION}

Much effort has been devoted in marine microbial ecology to determining the role of bacterioplankton in the flux of carbon in the ocean, resulting in a good knowledge of the spatial variability of bacterial activity (e.g. Ducklow \& Carlson 1992, Ducklow 2000). The advent of molecular biological techniques in the late 1980s allowed the examination of the diversity of prokaryotes in oceanic waters and the identification of abundant bacterial groups in the sea (Giovanonni \& Rappé 2000). However, we still lack knowledge about the spatial distribution of dominant prokaryotes at both large and small scales in the ocean (but see Suzuki et al. 2001 and Zubkov et al. 2002) and, more importantly, we largely ignore their in situ phenotypic characteristics. 
Martinez et al. (1996) found that marine bacterial isolates showed different metabolic and enzymatic properties, suggesting that phylogenetic diversity may be a critical factor to consider when analyzing spatial and temporal patterns of bacterial activity. Experimental studies have subsequently shown that shifts in the composition of marine bacterial assemblages can be associated with changes in bacterial growth and activity rates (Pinhassi et al. 1999, Riemann et al. 2000, Kirchman et al. 2004). However, the biogeochemical implications of the phylogenetic diversity of marine bacterial assemblages are poorly understood, because few studies have simultaneously compared in situ bacterial assemblage structure with carbon processing, particularly in oceanic open waters (but see Reinthaler et al. 2005, Winter et al. 2005).

Here, we examined the relationship between bacterial assemblage structure, environmental, and carbon metabolism parameters throughout an oceanic transition zone (bottom depth > $1000 \mathrm{~m}$ ) between the North Atlantic Subtropical Gyre and the NW African upwelling. Upwelling areas are characterized by a major input of inorganic nutrients, which leads to increased phytoplankton productivity and bacterial heterotrophic production (e.g. Cuevas et al. 2004). In our sampling area, the Cape Blanc upwelling waters also showed higher bacterial abundance and production than did the oligotrophic stations (Alonso-Sáez et al. 2007). In this study, we determined whether changes in bacterial assemblage composition are associated with the observed changes in bacterial carbon dynamics, and whether particular communities could be associated with particular patterns of bacterial carbon processing. The effects of the underlying environmental variables on bacterial assemblage structure and carbon metabolism were also investigated.

\section{MATERIALS AND METHODS}

Location and sampling. The study was conducted along 2 transects from NW African coastal waters to open waters of the North Atlantic Subtropical Gyre (Fig. 1) during a cruise on board 'BIO-Hespérides' (COCA-II: 20 May to 10 June 2003). Water was collected from the surface ( $5 \mathrm{~m}$ depth) at 10 stations, and temperature, salinity and fluorescence were also recorded using a CTD system (Mark III-IOC) mounted on a General Oceanic rosette sampler equipped with twenty-four 121 Niskin bottles.

Basic data. The samples $(250 \mathrm{ml})$ were filtered through Whatman GF/F filters to determine the chlorophyll a (chl a) concentration. The filters were homogenized and kept refrigerated in the dark and pigments extracted in $90 \%$ acetone for ca. $1 \mathrm{~h}$.

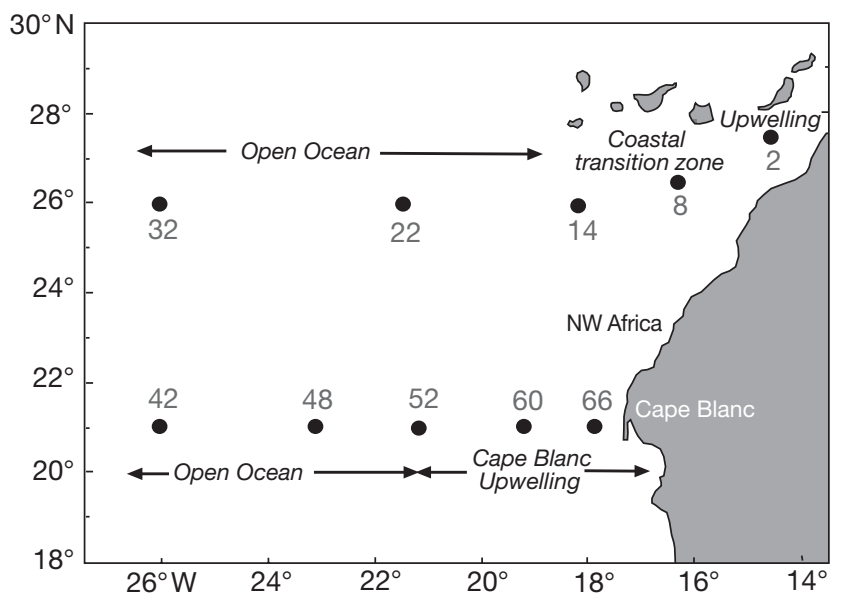

Fig. 1. Location of sampling area and stations in the NE Atlantic. Different areas are characterized according to hydrographical data (Alonso-Sáez et al. 2007)

Fluorescence of the extracts was measured in a Turner Designs fluorometer. Samples (2 l) for particulate organic carbon (POC) were filtered through combusted $\left(450^{\circ} \mathrm{C}, 12 \mathrm{~h}\right) 25 \mathrm{~mm}$ Whatman GF/F filters. The filters were wrapped in combusted aluminum foil and frozen at $-20^{\circ} \mathrm{C}$. In the laboratory, the filters were dried overnight at $65^{\circ} \mathrm{C}$ in a desiccator with $\mathrm{HCl}$ fumes to remove carbonates, and finally dried overnight in a desiccator with silica gel. Previous to analysis, samples were packed into ultra-clean tin disks. The carbon analyses were performed on a Perkin Elmer-2400 CHN elemental analyzer according to the Joint Global Ocean Flux Study (JGOFS) protocol (UNESCO 1994). Dissolved inorganic nutrients (nitrate and phosphate) were measured on an autoanalyzer using standard colorimetric methods (Hansen \& Koroleff 1999).

Denaturing gradient gel electrophoresis (DGGE). Surface microbial biomass was collected by sequentially filtering around $2 \mathrm{l}$ of seawater through a $3 \mu \mathrm{m}$ polycarbonate filter (Poretics, $47 \mathrm{~mm}$ ) and a $0.2 \mu \mathrm{m}$ polycarbonate filter (Poretics, $47 \mathrm{~mm}$ ) under gentle pressure. We used these last filters for the analysis. The filters were stored in cryovials filled with $1.8 \mathrm{ml}$ of lysis buffer (50 mM Tris-HCl pH 8.3, 40 mM EDTA pH 8.0, $0.75 \mathrm{M}$ sucrose) and kept at $-80^{\circ} \mathrm{C}$. Microbial biomass was treated with lysozyme, proteinase $K$ and sodium dodecyl sulfate (SDS), and the nucleic acids were extracted with phenol and concentrated in a Centricon-100 (Millipore) as described by Schauer et al. (2000). DGGE and gel analysis were essentially performed as described previously (Schauer et al. 2000). Briefly, 16S rRNA gene fragments (around $550 \mathrm{bp}$ in length) were amplified by PCR, using the universal primer $907 \mathrm{rm}$ and the bacterial-specific primer 358f, with a GC-clamp. The PCR products were loaded on a $6 \%$ polyacrylamide gel with a DNA-denaturant gradi- 
ent ranging from 40 to $80 \%$. The gel was run at $100 \mathrm{~V}$ at $60^{\circ} \mathrm{C}$ for $16 \mathrm{~h}$ in $1 \times$ TAE (Tris-Acetate-EDTA) running buffer. DGGE gel images were analyzed using the Diversity Database software (BIO-RAD).

Catalyzed Reporter Deposition-Fluorescence In Situ Hybridization (CARD-FISH). Samples were fixed with formaldehyde $(3.6 \%$ final concentration, overnight at $4{ }^{\circ} \mathrm{C}$ ), filtered and stored at $-20^{\circ} \mathrm{C}$ until processing using the protocol of Pernthaler et al. (2004). Filters were embedded in agarose $(0.1 \% \mathrm{wt} / \mathrm{vol})$ and permeabilized at $37^{\circ} \mathrm{C}$ with lysozyme $\left(10 \mathrm{mg} \mathrm{ml}^{-1} ; 0.05 \mathrm{M}\right.$ EDTA, $0.1 \mathrm{M}$ Tris-HCl; Fluka) for $60 \mathrm{~min}$ and achromopeptidase $\left(60 \mathrm{U} \mathrm{ml}^{-1} ; 0.01 \mathrm{M} \mathrm{NaCl}, 0.01 \mathrm{M}\right.$ Tris- $\mathrm{HCl}$, $\mathrm{pH} 7.6$; SIGMA) for $30 \mathrm{~min}$. For the hybridization $\left(35^{\circ} \mathrm{C}\right.$, overnight), $3 \mu \mathrm{l}$ of horseradish peroxidase (HRP)labeled probe working solution (50 ng $\mathrm{\mu l}^{-1}$, www.biomers.net) were added to $900 \mu \mathrm{l}$ of hybridization buffer $\left(\mathrm{HB}_{;}, 0.9 \mathrm{M} \mathrm{NaCl}, 20 \mathrm{mM}\right.$ Tris- $\mathrm{HCl}, 10 \%$ dextran sulfate wt/vol, $0.02 \%$ SDS, and $1 \%$ blocking reagent) containing the following percentages of formamide: $55 \%$ for EubI-III (mixture of probes Eub338, Eub II, and Eub III; Amann et al. 1990, Daims et al. 1999), Ros537 (Eilers et al. 2001), Gam42a and CF319a (Amann et al. 1990), and $20 \%$ for Eury806 (Teira et al. 2004), Cren554 (Massana et al. 1997) and Non338 (Wallner et al. 1993). A higher concentration of probe $(9 \mu \mathrm{l}$ in $900 \mu \mathrm{l} \mathrm{HB}, 45 \%$ formamide) was used to detect the cells with SAR11-441R (Morris et al. 2002) and Alf968 (Neef 1997) probes. Probe Gam42a was used with a Bet42a competitor oligonucleotide (Manz et al. 1992). Results of hybridization with the probe Non338 (negative control) never exceeded $1 \%$ of DAPI counts, and were not subtracted from the CARD-FISH counts. Filters were washed for 5 $\min \left(37^{\circ} \mathrm{C}\right)$ in pre-warmed washing buffer and subsequently incubated for $15 \mathrm{~min}$ at $46^{\circ} \mathrm{C}$ in $1 \mathrm{ml}$ of amplification buffer with $4 \mu \mathrm{l}$ of tyramide-alexa $488\left(1 \mathrm{mg} \mathrm{ml}^{-1}\right)$ containing $p$-iodophenylboronic acid (20 mg per $1 \mathrm{mg}$ tyramide). Finally, filter sections were mounted in a $4: 1$ Citifluor-Vecta Shield mixture containing 4'-6'-diamidino-2-phelylindole (DAPI; final concentration $1 \mu \mathrm{g}$ $\mathrm{ml}^{-1}$ ) and visualized in a Nikon epifluorescence microscope. Between 500 and 1000 DAPI-stained cells were counted per sample in a minimum of 10 fields.

Flow cytometry. Prokaryotic abundance and the percentage of high nucleic acid (HNA) cells were measured by flow cytometry (Gasol \& del Giorgio 2000). Samples were run in a Becton and Dickinson FACSCalibur cytometer after staining with Syto13 $(2.5 \mu \mathrm{M}$, Molecular Probes). Prokaryotes were detected by their signature in a plot of side scatter (SSC) vs. FL1 (green fluorescence). Regions were established on the SSC vs. green fluorescence plot in order to discriminate cells with HNA content from cells with low nucleic acid (LNA) content. The cell abundance was determined for each subgroup. Prokaryotic biomass was calculated from abundance assuming a conservative carbon content of $12 \mathrm{fg} \mathrm{C}$ cell $^{-1}$ (Fukuda et al. 1998).

Bacterial carbon processing and enrichment experiments. Details of the methodology used to determine bacterial carbon flux in the area are presented elsewhere (Alonso-Sáez et al. 2007). Briefly, bacterial heterotrophic production (BHP) was estimated from the incorporation of ${ }^{3} \mathrm{H}$-leucine (Leu, protein biosynthesis) and thymidine (TdR, DNA biosynthesis). Both tracers were used at $40 \mathrm{nM}$ (final concentration) in incubations of 2 to $4 \mathrm{~h}$. The samples were processed by the centrifugation method of Smith \& Azam (1992). Carbon-to-Leu empirical conversion factors (eCFs) were experimentally determined from dilution cultures at each station and calculated following the cumulative method (Bjørnsen \& Kuparinen 1991). Bacterial respiration (BR) measurements were made following the decrease in dissolved oxygen in the bacterial fraction in $24 \mathrm{~h}$ incubations by Winkler titrations, based on colorimetric end-point detection. We assumed a respiratory quotient of 0.88 (Williams \& del Giorgio 2005). Finally, the effects of organic (glucose and acetate; $1 \mu \mathrm{M}$ each) and/or inorganic (nitrate, ammonium and phosphate; $0.5 \mu \mathrm{M}$ each) enrichments on BHP were studied in surface samples from all stations (except Stn 2). BHP was measured 24 to $48 \mathrm{~h}$ after the nutrient addition and was compared with 2 unamended controls. We accepted a positive response to the enrichment over the control when BHP increased by a factor of $>2$ in the nutrient amended treatments.

Statistical analysis. A matrix was constructed for all DGGE lanes, taking into account the relative contribution of each band (in \%) to the total intensity of the lane. Based on this matrix, we obtained a dendrogram using Ward's clustering method (Ward 1963; euclidean distances, Statistica 6.0), and ordinations by non-metric multidimensional scaling (nMDS; Kruskal \& Wish 1978, Clarke \& Green 1988) and principal component analysis (PCA; Chatfield \& Collins 1980). nMDS is a nonparametric procedure that uses ranks of the similarities between samples to construct a map in which the positions of the samples reflect as closely as possible the dissimilarities among them. For this analysis, all DGGE bands were included (Bray-Curtis similarity index, Primer version 5). PCA reduces the complexity of multivariate data, creating new linear variables that encompass most of the variability in the original data. This analysis was performed taking into account only the more significant bands (those appearing in more than 2 samples and with a relative intensity of $>5 \%$ ), in order to reduce the number of variables used in the analysis (Statistica version 6.0). A PCA performed with the total number of bands resulted in a nearly identical ordination of the samples. For nMDS and PCA analyses, DGGE band percentages were arcsine transformed. 
The associations among environmental factors, bacterial assemblage structure (DGGE band pattern), and carbon metabolism parameters were analyzed by the RELATE routine of Primer software (version 5, Clarke \& Warwick 1994). This routine performs correlations of similarity matrices in a procedure similar to a Mantel test (Mantel 1967), except that the correlation is not the standard product-moment Pearson correlation (of a standard Mantel test) but rather Spearman's non-parametric rank correlation (rho). The statistical significance of the coefficient rho was obtained by a simple permutation test (999 permutations). Correlations were performed between 3 similarity matrices, which were constructed based on (1) DGGE banding patterns (arcsine transformed), (2) abiotic data (temperature, salinity, chl $a$, phosphate and nitrate concentrations; log-transformed), and (3) carbon processing variables (BHP measured by Leu uptake using eCFs, BHP measured by TdR uptake rates using a standard conversion

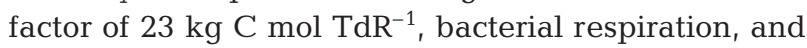
bacteria biomass; log-transformed, data shown in Table 1). Bray-Curtis similarities (for DGGE band patterns) and euclidean distances (for environmental and carbon metabolism data) were used to construct the similarity matrices (Primer version 5).

\section{RESULTS}

We visited 10 stations distributed along a northern $\left(26^{\circ} \mathrm{N}\right)$ and southern $\left(21^{\circ} \mathrm{N}\right)$ transect in the NE Atlantic Ocean (Fig. 1). The northern transect extended offshore from the boundary of the NW African coastal upwelling. An upwelling filament affected the station closest to the coast (Stn 2). Stns 8 and 14 were located in the coastal transition zone, and Stns 22 and 32 exhibited oceanic characteristics. The southern transect extended from the Cape Blanc coastal upwelling waters to the open ocean, crossing the Cape Vert Frontal Zone (CVFZ). The influence of upwelling waters reached as far as Stn 52, which was the limit between the upwelling area and oceanic waters. Further details on the hydrography of the stations are presented elsewhere (Alonso-Sáez et al. 2007).

DGGE analysis of the samples yielded a total of 40 unique bands with a mean $( \pm \mathrm{SD})$ of $18 \pm 2$ bands per sample and little variation among stations (range 15 to 22 bands, Fig. 2). Analysis of the DGGE fingerprints (Ward's clustering method) revealed a separation between the stations affected by upwelling waters (Stns 2, 52, 60 and 66) and the offshore stations (Fig. 2). The dendrogram showed further separation of the offshore stations into 2 clusters: (1) southern transect stations (Stns 42, 48) and (2) northern transect stations (Stns 8, 14, 22, 32). A dendrogram of the DGGE band profile matrix constructed using the UPGMA method maintained the same general structure with the exception of Stn 8, which appeared as an ungrouped branch within the offshore cluster (image not shown).

The ordination of stations by nMDS and PCA, based on the DGGE band patterns, agreed with the clustering results. A separation of the upwelling area from offshore stations was clearly identifiable, as was a separation of the south transect from the offshore stations of the north transect (Fig. 3). PCA simplified the DGGE band patterning into 3 new linear variables that encompassed most of the variability in the original data ( $71 \%$ of total variance). The first 3 principal components (PCs) of bacterial assemblage structure were correlated with several environmental or bacterial carbon processing variables. The first principal component (PC1, 43\% of total variance) was correlated with

Table 1. Summary of diagnostic results of BHP limitation experiments, \% of HNA cells, and data included in the carbon metabolism PCA. BBM: bacterial biomass; BHP1: bacterial heterotrophic production measured by Leu uptake, using eCFs; BHP2: BHP measured by TdR uptake using a theoretical conversion factor of $23 \mathrm{~kg} \mathrm{C}$ mol TdR ${ }^{-1}$; BR: bacterial respiration: NT: northern transect offshore; UPW: upwelling zone; ST: southern transect offshore. These data are presented and discussed in a separate study (Alonso-Sáez et al. 2007)

\begin{tabular}{|c|c|c|c|c|c|c|c|}
\hline Zone & Stn & $\begin{array}{c}\text { BBM } \\
\left(\mu \mathrm{C} \mathrm{C}^{-1}\right)\end{array}$ & $\begin{array}{c}\text { BHP1 } \\
\text { (protein synthesis) } \\
\left(\mu \mathrm{C} \mathrm{C}^{-1} \mathrm{~d}^{-1}\right)\end{array}$ & $\begin{array}{l}\text { BHP2 (DNA synthesis) } \\
\left(\mu \mathrm{g} \mathrm{C}^{-1} \mathrm{~d}^{-1}\right)\end{array}$ & 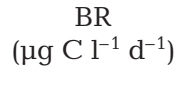 & $\begin{array}{l}\text { HNA cells } \\
(\%)\end{array}$ & $\begin{array}{c}\text { BHP limitation } \\
\text { organic/inorganic } \\
\text { nutrient }\end{array}$ \\
\hline NT-UPW & 2 & 18 & 0.36 & 2.53 & 10.9 & 80 & nd \\
\hline NT & 8 & 16 & 0.14 & 0.96 & 10.6 & 35 & carbon \\
\hline NT & 14 & 10 & 0.08 & 0.66 & 9.7 & 36 & carbon \\
\hline NT & 22 & 16 & 0.03 & 0.87 & 2.2 & 31 & phosphorus \\
\hline NT & 32 & 8 & 0.63 & 7.73 & 11.3 & 38 & co-limitation \\
\hline ST-UPW & 66 & 51 & 1.65 & 1.98 & 16.4 & 77 & carbon \\
\hline ST-UPW & 60 & 68 & 2.15 & 3.21 & 30.8 & 56 & carbon \\
\hline ST-UPW & 52 & 11 & 0.26 & 0.59 & 12.1 & 40 & carbon \\
\hline ST & 48 & 9 & 0.37 & 3.48 & 22.2 & 31 & no limitation \\
\hline $\mathrm{ST}$ & 42 & 5 & 0.32 & 7.62 & 17.7 & 34 & no limitation \\
\hline
\end{tabular}



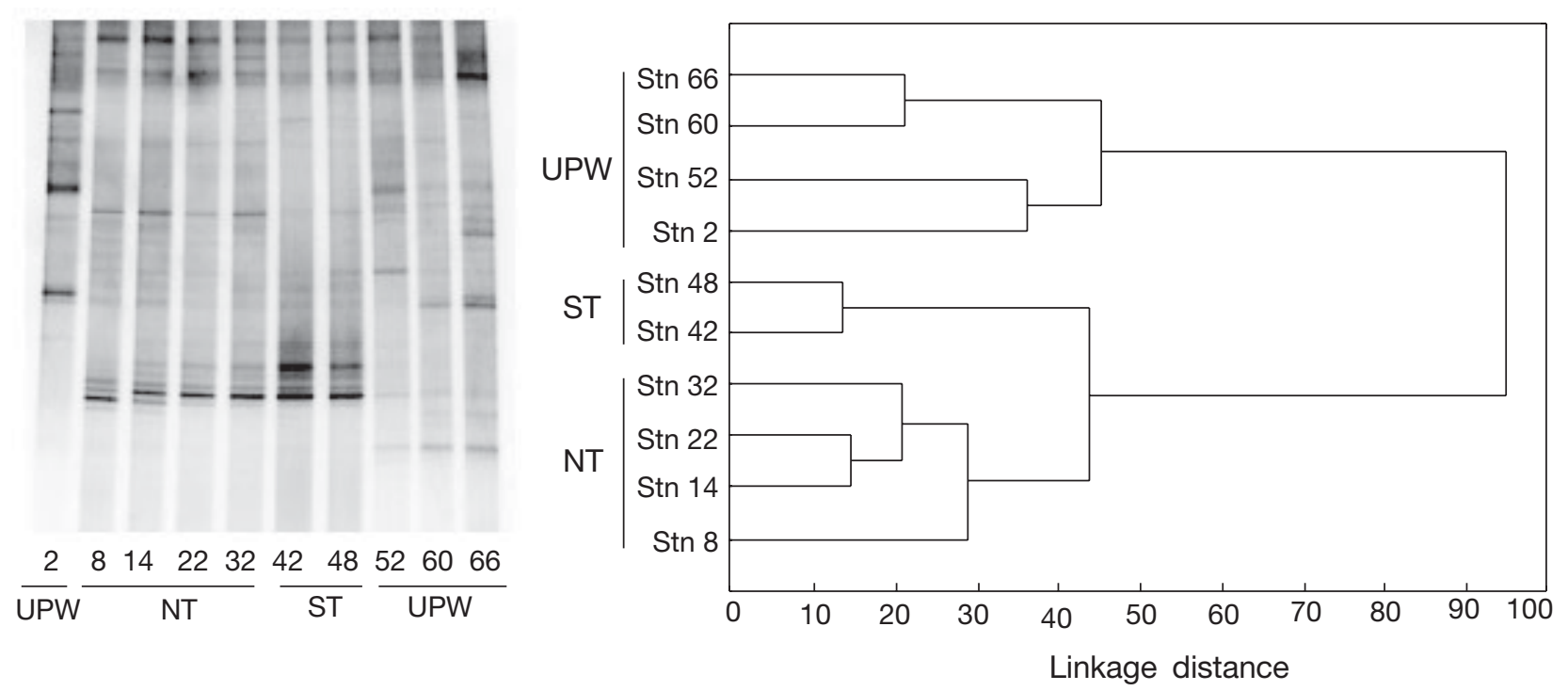

Fig. 2. DGGE pattern of surface stations and dendrogram classification (Ward's method, euclidean distances according to banding patterns). UPW: upwelling zone; ST: southern transect offshore; NT: northern transect offshore

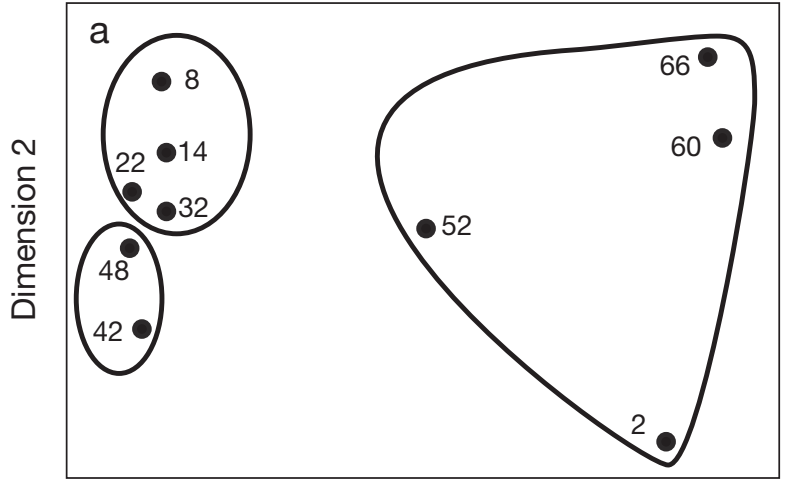

Dimension 1

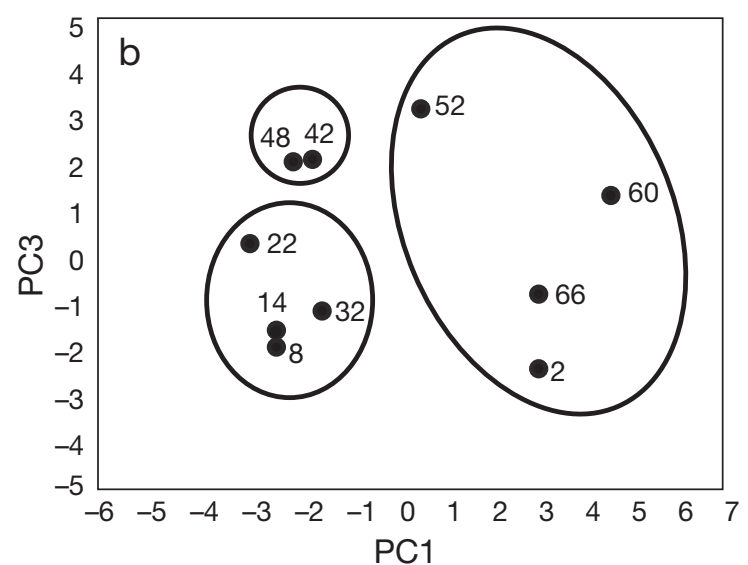

Fig. 3. (a) nMDS and (b) PCA of bacterial assemblage composition data (DGGE banding pattern). Stations (numbered) were clustered according to Ward's clustering method results (see Fig. 2)

salinity and chl a (Table 2), as well as with several bacterial parameters such as bacterial production, biomass or percentage of HNA cells (Table 2). PC2 (14.8\% of total variance) was not correlated with any of these environmental or biotic parameters, and PC3 (13.5\% of total variance) was only correlated with temperature (Table 2).

The relationship between bacterial assemblage structure, carbon processing, and environmental factors was assessed through Spearman rank correlation of the corresponding similarity matrices. We found a strong relationship between environmental data and bacterial assemblage structure in all samples (Spearman's $r h o=0.70, p<0.01$ ) and a weaker but significant relationship between bacterial assemblage structure and carbon processing patterns (Spearman's rho =
0.36, $\mathrm{p}<0.05)$. The relationship between environmental parameters and carbon processing data was not statistically significant ( $\mathrm{p}>0.05)$.

Results from experiments exploring the nutrient limitation of bacterial production (Table 1) agreed relatively well with the grouping of stations based on the bacterial assemblage structure obtained by nMDS or PCA (Fig. 3). The upwelling Stns 52, 60 and 66, which clustered together according to DGGE band patterns, were characterized by carbon limitation (Table 1). At Stns 42 and 48, which also showed a related bacterial assemblage structure, bacteria responded in a similar way to the experimental additions showing no apparent limitation by inorganic or organic resources. We found higher variability in the response to nutrient enrichment within the group of northern offshore sta- 
Table 2. Correlation coefficients (Spearman's rho) between the scores of stations on PC1, PC2 and PC3 generated by the bacterial diversity PCA, and environmental (temperature, salinity, and concentrations of POC $[\mu \mathrm{M}]$ and chl a $\left[\mu \mathrm{g} \mathrm{l}^{-1}\right]$,) and bacterial variables (bacterial production estimated by leucine [BHP Leu, $\mu \mathrm{g} \mathrm{C}^{-1} \mathrm{~d}^{-1}$ ] and thymidine uptake [BHP

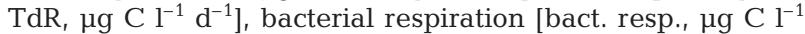
$\mathrm{d}^{-1}$ ], bacterial biomass [bact. biomass, $\mu \mathrm{g} \mathrm{C}^{-1}$ ], and \% of HNA cells). Sample size (n) varies between 9 and 10; \% of variance of bacterial diversity explained by each PC shown, ${ }^{*} \mathrm{p} \leq 0.05,{ }^{* *} \mathrm{p} \leq 0.01$

\begin{tabular}{|lccc|}
\hline & $\begin{array}{c}\text { PC1 }(43 \% \\
\text { variance) }\end{array}$ & $\begin{array}{c}\text { PC2 }(15 \% \\
\text { variance) }\end{array}$ & $\begin{array}{r}\text { PC3 }(14 \% \\
\text { variance })\end{array}$ \\
\hline $\begin{array}{l}\text { Environmental } \\
\text { Temperature }\end{array}$ & -0.56 & -0.47 & $0.64^{*}$ \\
Salinity & $-0.73^{*}$ & 0.42 & 0.03 \\
POC & 0.63 & 0.18 & 0.25 \\
Chl a & $0.76^{* *}$ & -0.34 & 0.02 \\
Bacterial & & & \\
BHP (Leu) & $0.84^{*}$ & 0.27 & 0.17 \\
BHP (TdR) & 0.28 & 0.30 & 0.05 \\
Bact. resp. & $0.66^{*}$ & -0.09 & 0.58 \\
Bact. biomass & $0.64^{*}$ & -0.37 & -0.32 \\
\%HNA & $0.82^{* *}$ & -0.18 & -0.32 \\
& & & \\
\hline
\end{tabular}

tions, which included stations located in the coastal transition zone and the open ocean. Nevertheless, both coastal transition zone stations (Stns 8 and 14), which were close in the PCA ordination, exhibited carbon limitation of bacterial production (Table 1).

In situ abundances of bacterial phylogenetic groups were determined by CARD-FISH, which on average detected $66 \%$ of the DAPI-stained cells with the mixture of 3 HRP-probes that covered the Bacteria domain (Eub+ cells, Eub 338-II-III; Fig. 4). The proportion of cells hybridizing with archaeal probes (Eury806 and
Cren554) in surface waters was below $3 \%$ of DAPIstained cells (data not shown).

In the upwelling area, a higher percentage of Eub+ cells was identified with probes for Alpha- and Gammaproteobacteria and Bacteroidetes groups (Alf968, Gam42a, CF319a; average $87 \%$ of Eub+ cells) than that identified in offshore waters (Fig. 4). Alphaproteobacteria was the most abundant group in both transects, comprising on average $36 \%$ of the DAPI-stained cells (55\% of Eub+ cells). The SAR11 clade accounted for the majority of Alphaproteobacteria cells. Bacteroidetes and Gammaproteobacteria constituted on average 8 and $7 \%$ of Eub+ cells, respectively, and like the Roseobacter group were detected in significantly higher proportions in the upwelling zone (Student's $t$-test, $\mathrm{p}<0.05$; Fig. 4).

We analyzed the correlation between the abundance of bacterial groups detected by CARD-FISH and environmental or bacterial variables, including the PCs that captured most of the variation of the banding DGGE pattern. The abundance of Roseobacter and Gammaproteobacteria was highly correlated with salinity and concentration of POC and chl $a$, and Bacteroidetes showed a strong negative correlation with temperature (Table 3). The abundance of these 3 groups was significantly correlated with the percentage of HNA cells, as well as with the PC1 of bacterial diversity PCA. Although the abundance of Roseobacter was significantly correlated with bacterial heterotrophic production (estimated by leucine uptake with eCFs), the abundance of total Alphaproteobacteria was negatively correlated with this parameter and also with bacterial respiration (Table 3 ). The SAR 11 group was not significantly correlated with any of these parameters.

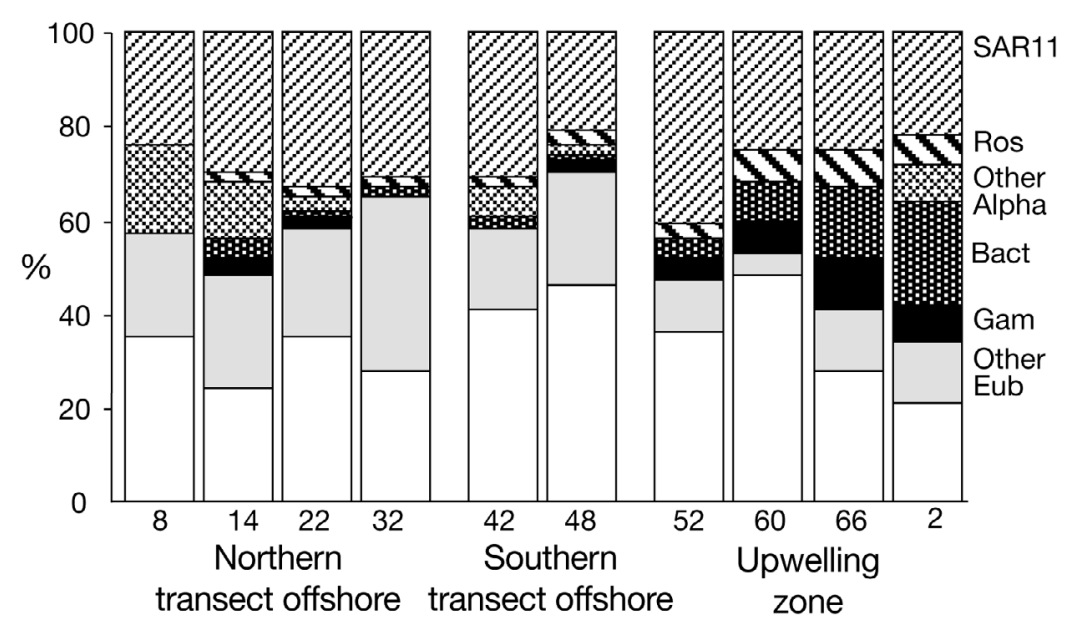

Fig. 4. Abundance (\%) of bacterial groups detected by HRP-probes (CARDFISH), scaled to DAPI counts. Ros: Roseobacter; Alpha: Alphaproteobacteria; Gam: Gammaproteobacteria; Bact: Bacteroidetes; Eub: Eubacteria

\section{DISCUSSION}

The composition of bacterial assemblages appears to be uniform over large oceanic areas (Acinas et al. 1997), even when significant differences in environmental or bacterial activity parameters exist (Riemann et al. 1999, Riemann \& Middelboe 2002). As an example, Arrieta et al. (2004) found that the phylogenetic composition of the bacterioplankton community did not change after an iron fertilization experiment in the Southern Ocean, despite significant changes in bacterial production, abundance and ectoenzymatic activities. This suggests that bacterial community structure can remain stable under different trophic conditions, and probably per- 
forms with redundancy in carbon processing.

In contrast, other studies have reported substantial spatial variability in bacterial assemblage structure, particularly in upwelling and frontal systems (Kerkhof et al. 1999, Suzuki et al. 2001, Pinhassi et al. 2003). To know whether changes at the bacterial diversity level can affect the in situ carbon metabolism is crucial to understanding whether bacterioplankton can be regarded as a uniform unit, or if a more detailed phylogenetic picture is needed in carbon flux models. However, such linkage has rarely been explored in oceanic waters, and those studies that do exist almost exclusively compare changes in bacterial richness (number of taxa) with several carbon processing parameters (Reinthaler et al. 2005, Winter et al. 2005).

Here, we explored the linkage using a multivariate approach, in which we analyzed changes in bacterial assemblage composition by DGGE and, simultaneously, a range of bacterial carbon processing variables. PCA was used in order to reduce the complexity of bacterial community structure (DGGE banding patterns) into a few linear variables, which were subsequently correlated with environmental and bacterial variables, similarly to previous studies in different systems (e.g. Fry et al. 2006). The ordination of the stations with the PCA analysis of DGGE banding patterns was highly coherent, with results from a non-parametric approach based solely on similarity distances of stations (nMDS) and Ward's clustering method.

\section{Spatial variability in bacterial assemblage structure in the NE Atlantic Ocean}

In previous studies, DGGE provided insights into changes in microbial diversity on temporal and spatial scales (Murray et al. 1998, Schauer et al. 2000, 2003); however, as with all PCR-based methods, it is potentially prone to problems and biases (Wintzingerode et al. 1997). The use of a PCR-independent method (i.e. CARD-FISH) allowed the identification and quantification of the dominant bacterial groups by the use of specific probes. These complementary approaches have been seldom compared (Castle \& Kirchman 2004) and, in our study, showed good agreement with regard to the differences in bacterial assemblage structure throughout the area, especially between the upwelling and offshore stations. As an example, the high similarity shown by CARD-FISH between Stn 66 (closest to the upwelling area in the southern transect) and Stn 2 (upwelling filament reaching the northern transect), despite being separated by almost $800 \mathrm{~km}$, is particularly evident and indicates the role of oceanographic regimes in shaping bacterial community structure.

There are still few studies in open ocean waters that use FISH to provide a detailed description of the composition of bacterioplankton, including probes for broad and more specific phylogenetic groups. Glöckner et al. (1999) provided first insights into differences in assemblage compositions of different marine regions with group-specific oligonucleotide probes. More recently, Fuchs et al. (2005) used the improved CARD-FISH protocol (Pernthaler et al. 2002) to study the composition of bacterioplankton in different areas of the Arabian Sea, and found marked differences in the proportions of some specific groups such as SAR86, SAR11 and SAR116. In our study, we also used the CARD-FISH methodology, which probably contributed to the high detection efficiency of groups - such as SAR11 - in oligotrophic oceanic samples.

On average, we found that SAR11 made up $28 \%$ of the DAPI counts, which are values comparable to the few previous studies that have detected this group by means of FISH with the use of multiple probes (Morris et al. 2002, Malmstrom et al. 2004). Our findings corroborate that SAR11 is one of the most abundant bacterial groups in the oceans, and suggest that, in terms of contribution to assemblage composition, this clade was not favored by upwelling conditions (in agreement with the results of Fuchs et al. 2005). 
In contrast, we found that Roseobacter, Gammaproteobacteria and Bacteroidetes comprised maximum contributions to assemblage structure in the upwelling region. The Roseobacter group has been detected in high proportions in association with natural phytoplankton blooms (González et al. 2000, Suzuki et al. 2001). Furthermore, members of this group have been suggested to be active colonizers of particles under algal bloom conditions (Riemann et al. 2000). Similarly, the Gammaproteobacteria group includes members with high growth rates, potentially favored by nutrient enrichment pulses (Eilers et al. 2000, Fuchs et al. 2000, Pinhassi \& Berman 2003, Yokokawa et al. 2004).

The Bacteroidetes cluster has also been found in upwelling events (Suzuki et al. 2001), and their members have a high ability to degrade high-molecular weight compounds (Cottrell \& Kirchman 2000, Kirchman 2002). This carbon source was probably abundant in the upwelling area, where we also encountered high POC concentrations (Alonso-Sáez et al. 2007). Indeed, members of the Bacteroidetes group are quantitatively important components of both the free-living and the particulate fraction of bacterial assemblages during phytoplankton blooms (Riemann et al. 2000, Abell \& Bowman 2005).

\section{Link between environmental factors, bacterial assemblage structure, and carbon processing}

The link between bacterial assemblage structure and carbon metabolism is a difficult issue to elucidate under in situ conditions, because environmental factors probably affect both parameters. In this study, we found that environmental factors significantly affected the composition of the bacterial assemblages (Spearman's rho $=0.7, \mathrm{p}<0.01$ ), but not the pattern of carbon processing. The PC1 of bacterial assemblage structure, which included most of the variation of the DGGE banding pattern, was significantly correlated with environmental variables characteristic of the upwelling, such as salinity and chl a. These results are in agreement with reported changes in bacterial diversity in upwelling regimes (Suzuki et al. 2001).

The composition of the bacterial assemblage was also significantly correlated with the bacterial processing of carbon; however, the strength of this relationship was relatively weak (Spearman's rho $=0.36, \mathrm{p}<$ 0.05). Similarly, the PC1 of the DGGE banding pattern was significantly correlated with bacterial production (Leu uptake) and biomass, suggesting that the community developing in the upwelling was performing differently in terms of carbon use.
The coupling between bacterial assemblage composition and carbon metabolism contrasts with the results of some other studies of marine open waters that have reported no such relationship, like the experimental study by Arrieta et al. (2004). However, a recent study by Fuhrman et al. (2006) demonstrated that the temporal patterns in distribution and abundance of bacterial taxa (analyzed by automated ribosomal intergenic space analysis, ARISA) off the Californian coast were significantly influenced by a range of abiotic and biotic factors, including TdR uptake. These results suggest low levels of redundancy in functional bacterial communities.

Pinhassi et al. (2003) suggested that not only quantitative but also qualitative differences in variables that affect bacterial growth are required to understand the variability in bacterioplankton assemblage composition. In their study across the Skagerrak front, these authors hypothesized that $\mathrm{N}$ vs. P limitation could affect the variability in bacterial assemblage structure. In contrast, Van Mooy et al. (2004), using the T-RFLP methodology, found that the growth response to different organic amendments was generally unrelated to bacterial assemblage structure in the North Pacific. In our case, nutrient limitation seemed to be generally related to bacterial assemblage structure, albeit with some exceptions.

\section{Relationship between the in situ abundance of bacterial groups and environmental or biotic parameters}

SAR11 was the dominant group of Alphaproteobacteria, and their abundance was not significantly correlated with any carbon processing variable. Although this group was shown in some studies to be highly active in the Sargasso Sea (by means of microautoradiography combined with FISH; Malmstrom et al. 2004), their activity seems to be significantly lower in more coastal waters such as the North Sea or the NW Mediterranean (Alonso \& Pernthaler 2006, L. AlonsoSáez et al. unpubl. data).

The percent contribution of Roseobacter was highly correlated with POC and chl $a$, suggesting that this group can be a good competitor under high levels of resources, efficiently consuming the carbon produced by the phytoplankton. This is in agreement with the common association of this lineage with phytoplankton cultures (Schäfer et al. 2002) or natural blooms (Suzuki et al. 2001). This group was also highly correlated with bacterial production, in agreement with their high single-cell activity in terms of substrate uptake (Alonso \& Pernthaler 2006, L. Alonso-Sáez et al. unpubl. data). 
The 3 groups Roseobacter, Gammaproteobacteria, and Bacteroidetes were positively correlated with the percentage of HNA cells (Table 3). The percentage of HNA cells has been shown correlate relatively well with bacterial activity in coastal waters (Lebaron et al. 2001, 2002). Shifts in bacterial metabolism have been associated with changes in the percentage of active cells (del Giorgio \& Bouvier 2002). Although the positive correlation is not a direct observation, it suggests that these groups could be composed of HNA ('active') bacteria. This would agree with the results of Zubkov et al. (2001), who sorted the HNA bacterial community of an offshore sample using flow cytometry and found high proportions of Bacteroidetes and Roseobacter within this group. On the contrary, SAR11 always fell in the LNA group in a study conducted in the Arabian Sea by Fuchs et al. (2005).

In summary, bacterial assemblage structure was highly influenced by environmental factors such as temperature, salinity and chl $a$, showing a distinct community in the upwelling region and spatial variability within offshore waters. Bacterial carbon metabolism was significantly correlated with bacterial assemblage structure, as shown by the Mantel procedure and the significant correlations between the PC1 of bacterial assemblage structure data and several carbon processing parameters. The bacterial groups Roseobacter and Gammaproteobacteria showed positive correlations with bacterial heterotrophic production and biomass, respectively. The SAR11 group, which was relatively constant throughout the area, did not correlate with any of these parameters. The correlative approaches, such as the one we used, can provide first insights into the link between bacterial assemblage structure, biotic and abiotic parameters. Even if correlations do not imply causality, it is of great interest to know whether changes in bacterial assemblages are associated with changes in carbon metabolism for carbon modeling and predictive purposes. Further studies that use single-cell techniques will undoubtedly help us to identify the groups with the most important role in the flux of carbon in the ocean, and accelerate the potential incorporation of bacterial assemblage structure into carbon cycle models.

Acknowledgements. Fieldwork was supported by the COCA (REN2000 1471-CO2-O1-MAR) and DEBACOCA (REN20014211-E) projects. Molecular work was funded by projects MICRODIFF (REN2001-2120/MAR), BASICS (EVK3-CT2002-00078) and GENMUMAR (CTM2004-02586/MAR). This is a contribution to the MARBEF European Network of Excellence (FP6-2002-Global-1). Financial support was provided by a Ph D fellowship from the Spanish government to L.A.S. We thank J. Felipe, S. Arrabal and G. Cuesto for their assistance in the laboratory and the staff of the Unidad de Tecnología Marina (UTM), the crew and other scientists aboard 'BIO-Hespérides' for their help during COCA cruises. C.
Duarte, C. Pedrós-Alió and R. Lombardo made valuable comments that improved the manuscript.

\section{LITERATURE CITED}

Abell GCJ, Bowman JP (2005) Colonization and community dynamics of class Flavobacteria on diatom detritus in experimental mesocosms based on Southern Ocean seawater. FEMS Microbiol Ecol 53:379-391

Acinas SG, Rodríguez-Valera F, Pedrós-Alió C (1997) Spatial and temporal variation in marine bacterioplankton diversity as shown by RFLP fingerprinting of PCR amplified 16S rDNA. FEMS Microbiol Ecol 24:27-40

Alonso C, Pernthaler J (2006) Concentration-dependent patterns of leucine incorporation in coastal picoplankton. Appl Environ Microbiol 72:2141-2147

Alonso-Sáez L, Gasol JM, Arístegui J, Vilas JC, Vaqué D, Duarte CM, Agustí S (2007) Large-scale variability in surface bacterial carbon demand and growth efficiency in the subtropical northeast Atlantic Ocean. Limnol Oceanogr 52(in press)

Amann RI, Binder BJ, Olson RJ, Chisholm SW, Devereux R, Stahl DA (1990) Combination of 16S rRNA-targeted oligonucleotice probes with flow cytometry for analyzing mixed microbial populations. Appl Environ Microbiol 56: 1919-1925

Arrieta JM, Weinbauer M, Lute C, Herndl GJ (2004) Response of bacterioplankton to iron fertilization in the Southern Ocean. Limnol Oceanogr 49:799-808

Bjørnsen PK, Kuparinen J (1991) Determination of bacterioplankton biomass, net production and growth efficiency in the Southern Ocean. Mar Ecol Prog Ser 71:185-194

Castle D, Kirchman DL (2004) Composition of estuarine bacterial communities assessed by denaturing gradient gel electrophoresis and fluorescence in situ hybridization. Limnol Oceanogr Methods 2:303-314

Chatfield C, Collins AJ (1980) Introduction to multivariate analysis. Chapman \& Hall, London

Clarke KR, Green RH (1988) Statistical design and analysis for a biological effects study. Mar Ecol Prog Ser 46: $213-226$

Clarke KR, Warwick RM (1994) Changes in marine communities: an approach to statistical analysis and interpretation. Phymouth Marine Laboratory, Plymouth

Cottrell MT, Kirchman DL (2000) Natural assemblages of marine Proteobacteria and members of the CytophagaFlavobacter cluster consuming low- and high-molecularweight dissolved organic matter. Appl Environ Microbiol 66:1692-1697

Cuevas LA, Daneri G, Jacob B, Montero P (2004) Microbial abundance and activity in the seasonal upwelling area off Concepción $\left(36^{\circ} \mathrm{S}\right)$, central Chile: a comparison of upwelling and non-upwelling conditions. Deep-Sea Res II 51:2427-2440

Daims H, Bruhl A, Amann R, Schleifer KH, Wagner M (1999) The domain-specific probe EUB338 is insufficient for the detection of all bacteria: development and evaluation of a more comprehensive probe set. Syst Appl Microbiol 22: 434-444

del Giorgio PA, Bouvier TC (2002) Linking the physiologica and phylogenetic successions in free-living bacterial communities along an estuarine salinity gradient. Limnol Oceanogr 47:471-486

Ducklow HW (2000) Bacterial production and biomass in the oceans. In: Kirchman DL (ed) Microbial ecology of the oceans. Wiley-Liss, New York, p 85-120 
Ducklow HW, Carlson CA (1992) Oceanic bacterial production. Adv Microb Ecol 12:113-181

Eilers H, Pernthaler J, Amann R (2000) Succession of pelagic marine bacteria during enrichment: a close look at cultivation-induced shifts. Appl Environ Microbiol 66:4634-4640

Eilers H, Pernthaler J, Peplies J, Glöckner FO, Gerdts G, Amann R (2001) Isolation of novel pelagic bacteria from the German Bight and their seasonal contributions to surface picoplankton. Appl Environ Microbiol 67:5134-5142

Fry JC, Webster G, Cragg BA, Weightman AJ, Parkes RJ (2006) Analysis of DGGE profiles to explore the relationship between prokaryotic community composition and biogeochemical processes in deep subseafloor sediments from the Peru Margin. FEMS Microbiol Ecol 58:86-98

Fuchs BM, Zubkov MV, Sahm K, Burkill PH, Amann R (2000) Changes in community composition during dilution cultures of marine bacterioplankton as assessed by flow cytometry and molecular biology techniques. Environ Microbiol 2:191-201

Fuchs BM, Woebken D, Zubkov MV, Burkill P, Amann R (2005) Molecular identification of picoplankton populations in contrasting waters of the Arabian Sea. Aquat Microb Ecol 39:145-157

Fuhrman JA, Hewson I, Schwalbach MS, Steele JA, Brown MV, Naeem S (2006) Annually reoccurring bacterial communities are predictable from ocean conditions. PNAS 103:13104-13109

Fukuda R, Ogawa H, Nagata T, Koike I (1998) Direct determination of carbon and nitrogen contents of natural bacterial assemblages in marine environments. Appl Environ Microbiol 64:3352-3358

Gasol JM, del Giorgio PA (2000) Using flow cytometry for counting natural planktonic bacteria and understanding the structure of planktonic bacterial communities. Sci Mar 64:197-224

Giovanonni SJ, Rappé M (2000) Evolution, diversity and molecular ecology of marine prokaryotes. In: Kirchman DL (ed) Microbial ecology of the oceans. Wiley-Liss, New York, p 47-84

Glöckner FO, Amann R, Alfreider A, Pernthaler J, Psenner R, Trebesius K, Schleifer KH (1996) An in situ hybridization protocol for detection and identification of planktonic bacteria. Syst Appl Microbiol 19:403-406

Glöckner FO, Fuchs BM, Amann R (1999) Bacterioplankton compositions of lakes and oceans: a first comparison based on fluorescence in situ hybridization. Appl Environ Microbiol 65:3721-3726

González JM, Simó R, Massana R, Covert JS, Casamayor EO, Pedrós-Alió C, Moran MA (2000) Bacterial community structure associated with a dimethylsulfoniopropionateproducing North Atlantic algal bloom. Appl Environ Microbiol 66:4237-4246

Hansen K, Koroleff FF (1999) Determination of nutrients. In: Grasshoff K, Kremling K, Ehrhardt M (eds) Methods of seawater analysis. Wiley-VCH, p 159-228

Kerkhof LJ, Voytek MA, Sherrell RM, Millie D, Schofield O (1999) Variability in bacterial community structure during upwelling in the coastal ocean. Hydrobiologia 401: 139-148

Kirchman DL (2002) The ecology of Cytophaga-Flavobacteria in aquatic environments. FEMS Microbiol Ecol 39:91-100

Kirchman DL, Dittel AI, Findlay SEG, Fischer D (2004) Changes in bacterial activity and community structure in response to dissolved organic matter in the Hudson River, New York. Aquat Microb Ecol 35:243-257

Kruskal JB, Wish M (1978) Multidimensional scaling. Sage Publications, Beverly Hills, CA
Lebaron P, Servais P, Agogué H, Courties C, Joux J (2001) Does the high nucleic acid content of individual bacterial cells allow us to discriminate between active cells and inactive cells in aquatic systems? Appl Environ Microbiol 67:1775-1782

Lebaron P, Servais P, Baudoux A, Bourrain M, Courties C, Parthuisot N (2002) Variations of bacterial-specific activity with cell size and nucleic acid content assessed by flow cytometry. Aquat Microb Ecol 28:131-140

Malmstrom RR, Kiene RP, Cottrell MT, Kirchman DL (2004) Contribution of SAR11 bacteria to dissolved dimethylsulfoniopropionate and amino acid uptake in the North Atlantic ocean. Appl Environ Microbiol 70:4129-4135

Mantel N (1967) The detection of disease clustering and a generalized regression approach. Cancer Res 27:209-220

Manz W, Amann R, Ludwig W, Wagner M, Schleifer KH (1992) Phylogenetic oligodeoxynucleotide probes for the major subclasses of Proteobacteria - Problems and solutions. Syst Appl Microbiol 15:593-600

Martinez J, Smith DC, Steward GF, Azam F (1996) Variability in ectohydrolytic enzyme activities of pelagic marine bacteria and its significance for substrate processing in the sea. Aquat Microb Ecol 10:223-230

Massana R, Murray AE, Preston CM, DeLong EF (1997) Vertical distribution and phylogenetic characterization of marine planktonic Archaea in the Santa Barbara channel. Appl Environ Microbiol 63:50-56

Morris RM, Rappé MS, Connon SA, Vergin KL, Slebold WA, Carlson CA, Giovanonni SJ (2002) SAR11 clade dominates ocean surface bacterioplankton communities. Nature 420: 806-810

Murray AE, Preston CM, Massana R, Taylor LT, Blakis A, Wu K, DeLong EF (1998) Seasonal and spatial variability of bacterial and archaeal assemblages in the coastal waters near Anvers Island, Antarctica. Appl Environ Microbiol 64:2585-2595

Neef A (1997) Anwendung der in situ-Einzelzell-Identifizierung von Bakterien zur Populationsanlayse in komplexen mikrobiellen biozönosen. $\mathrm{PhD}$ thesis, Technische Universität München

Pernthaler A, Pernthaler J, Amann R (2002) Fluorescence in situ hybridization and catalyzed reporter deposition for the identification of marine bacteria. Appl Environ Microbiol 68:3094-3101

Pernthaler A, Pernthaler J, Amann R (2004) Sensitive multicolor fluorescence in situ hybridization for the identification of environmental microorganisms. In: Kowalchuk GA, DeBruijn FJ, Head IM, Akkermans ADL, van Elsas JD (eds) Molecular microbiology manual. Kluwer Academic, Dordrecht, p 711-726

Pinhassi J, Berman T (2003) Differential growth response of colony-forming alpha- and gamma-Proteobacteria in dilution culture and nutrient addition experiments from Lake Kinneret (Israel), the eastern Mediterranean Sea, and the Gulf of Eilat. Appl Environ Microbiol 69:199-211

Pinhassi J, Azam F, Hemphälä J, Long RA, Martinez J, Zweifel UL, Hagström $\AA$ (1999) Coupling between bacterioplankton species composition, population dynamics, and organic matter degradation. Aquat Microb Ecol 17:13-26

Pinhassi J, Winding A, Binnerup S, Zweifel UL, Riemann B, Hagström Å (2003) Spatial variability in bacterioplankton community composition at the Skagerrak-Kattegat front. Mar Ecol Prog Ser 255:1-13

Reinthaler T, Winter C, Herndl G (2005) Relationship between bacterioplankton richness, respiration, and production in the Southern North Sea. Appl Environ Microbiol 71:2260-2266 
Riemann L, Middelboe M (2002) Stability of bacterial and viral community compositions in Danish coastal waters as depicted by DNA fingerprinting techniques. Aquat Microb Ecol 27:219-232

Riemann L, Steward GF, Fandino LB, Campbell L, Landry MR, Azam F (1999) Bacterial community composition during 2 consecutive NE Monsoon periods in the Arabian Sea studied by denaturing gradient gel electrophoresis (DGGE) of rRNA genes. Deep-Sea Res II 46:1791-1811

Riemann L, Steward GF, Azam F (2000) Dynamics of bacterial community composition and activity during a mesocosm diatom bloom. Appl Environ Microbiol 66:578-587

Schäfer H, Abbas B, Witte H, Muyzer G (2002) Genetic diversity of 'satellite' bacteria present in cultures of marine diatoms. FEMS Microbiol Ecol 42:25-35

Schauer M, Massana R, Pedrós-Alió C (2000) Spatial differences in bacterioplankton composition along the Catalan coast (NW Mediterranean) assessed by molecular fingerprinting. FEMS Microbiol Ecol 33:51-59

Schauer M, Balagué V, Pedrós-Alió C, Massana R (2003) Seasonal changes in the taxonomic composition of bacterioplankton in a coastal oligotrophic system. Aquat Microb Ecol 31:163-174

Smith DC, Azam F (1992) A simple, economical method for measuring bacterial protein synthesis rates in seawater using 3H-leucine. Mar Microb Food Webs 6:107-114

Suzuki MT, Preston CM, Chavez FP, DeLong EF (2001) Quantitative mapping of bacterioplankton populations in seawater: field tests across an upwelling plume in Monterey Bay. Aquat Microb Ecol 24:117-127

Teira E, Reinthaler T, Pernthaler A, Pernthaler J, Herndl G (2004) Combining catalyzed reported depositionfluorescence in situ hybridization and microautoradiography to detect substrate utilization by Bacteria and Archaea in the deep ocean. Appl Environ Microbiol 70: $4411-4414$

Editorial responsibility: Gerhard Herndl, Den Burg, Texel, The Netherlands
UNESCO (1994) Protocols for the Joint Global Ocean Flux Study (JGOFS) Core measurement. Intergovernmental Oceanographic Commission, manual and guides 29, p 1-169

Van Mooy BAS, Devol AH, Keil RG (2004) Relationship between bacterial community structure, light, and carbon cycling in the eastern subarctic North Pacific. Limnol Oceanogr 49:1056-1062

Wallner G, Amann R, Beisker W (1993) Optimizing fluorescent in situ hybridization with rRNA-targeted oligonucleotide probes for flow cytometric identification of microorganisms. Cytometry 14:136-143

Ward JH Jr (1963) Hierarchichal grouping to optimize an objective function. J Am Stat Assoc 58:236-244

Williams PJ, del Giorgio PA (2005) Respiration in aquatic ecosystems: history and background. In: del Giorgio PA, Williams PJ (eds) Respiration in aquatic ecosystems. Oxford University Press, New York, p 1-17

Winter C, Smit A, Herndl G, Weinbauer M (2005) Linking bacterial richness with viral abundance and prokaryotic activity. Limnol Oceanogr 50:968-977

Wintzingerode F, Göbel UB, Stackebrandt E (1997) Determination of microbial diversity in environmental samples: pitfalls of PCR-based rRNA analysis. FEMS Microbiol Rev 21:213-229

Yokokawa T, Nagata T, Cottrell MT, Kirchman DL (2004) Growth rate of the major phylogenetic bacterial groups in the Delaware estuary. Limnol Oceanogr 49:1620-1629

Zubkov MV, Fuchs B, Burkill PH, Amann R (2001) Comparison of cellular and biomass specific activities of dominant bacterioplankton groups in stratified waters of the Celtic Sea. Appl Environ Microbiol 67:5210-5218

Zubkov MV, Fuchs BM, Tarran GA, Burkill PH, Amann R (2002) Mesoscale distribution of dominant bacterioplankton groups in the northern North Sea in early summer. Aquat Microb Ecol 29:135-144

Submitted: March 13, 2006; Accepted: October 26, 2006 Proofs received from author(s): December 27, 2006 